\title{
An Analysis of Social Phenomenon of Metropolitan Short Stories for Literary Learning Based on Critical Appreciation
}

\author{
Hari Sunaryo \\ University of Muhammadiyah Malang, Indonesia \\ email: harinaryo@yahoo.co.id
}

\begin{abstract}
This study described the social phenomenon of metropolis short story as critical appreciation of literary learning. This study was conducted by employing sociology approach in literature. It analyzed the best short story collection of Jakarta International Literary Festival 2008-2011, entitled "Million Colors in Jakarta's Sky ". The study was conducted qualitatively. The data of the social facts of metropolitan life was analyzed in line with the context of its relevance to literary learning in schools. Based on the data analysis, it was found that 1) some social facts of metropolitan life were related to lifestyle, social environment, and occupation; 2) the relevant short story material for critical appreciation of literature learning for high school students used democratic group investigation model.
\end{abstract}

Keywords: social fact, metropolis short story, literary learning, critical appreciation

\section{INTRODUCTION}

Literary works have a strategic function for the development of human qualities. Through literature, humans (especially students) can broaden their insight and understanding of the issues of life and humanity. This is happening because literary works revealed various problems of human life. Moreover, the concern of literary learning emphasizes the humanistic side [1].

Literature is essentially an entity that never escapes from outside sources, such as: anthropology, sociology, psychology, religion, and so on. On the contrary, areas are often used as a subject of research through human interaction with literary works, lucrative activities, knowledge, consciousness, and entertainment [2].

As a world miniature, the function of literary works is to inventory many events that have been processed by using creativity and imagination patterns. What has been portrayed in literary works is a prototype of events that have occurred and may occur in everyday life. In fact, with its creativity and imaginative traits, literature has the greatest possibility to divert the diversity of the universe events into the semantic narratives, from the everyday life activities into the the fictional world. Furthermore, the representation of sociocultural facts in literary works is generally criticized through its dominant evocation in describing social phenomena. Such facts may lead literary works to be the tool of education [3].

The appreciation on quality literary works can give a lot of meaning. This is also certainly fulfill the indicators of quality appreciation. Quality literature has universal value and "eternity". Furthermore, the meaning gained from the appreciation of this quality literature will give a significant and unlimited impact of space and time. The case of literature appreciation learning in schools is still in literary aspect. It does not discuss about transcendental awareness yet. The activities are still limited on revealing the formal facts in literary texts. The learning process has not yet reached the exploration of the meaning behind the textual realities. The root of the problem related to the aspects of strategy, method, and instructional media [4].

\section{METHOD}

The research employed qualitative approach with descriptive analysis on social phenomenon of metropolitan life that was depicted through word, sentence, and story. There are 20 best short stories texts taken from Jakarta International Literary Festival in the year 2008-2011. Then, the texts were compiled into a book, entitled "Million Colors in Jakarta's Sky". The further analysis was sharpened by using logically, critically, and systematically meaning for the implementation of the literature appreciation in schools that was focusing on critical appreciation model.

\section{RESULT}

The findings of the social phenomenon that was represented in the metropolis short story, "Million Colors in Jakarta's Sky " are as follows:

\section{Metropolitan Social Reality in Short Story \\ 1. Lifestyle}

One of the things that marked the existence of a metropolis people was about a name. A name could indicate where people came from. It distinguished whether they are villagers or uptown people. Related to this matter, the phenomenon depicted in the short story was about the creative change of someone's name that was taken from the original name of the person.

(1) MARSELA. Marselamah is her real name. Before the tragic accident happened and killed both of her parents, Marsela has been living with her mother's relative to finish her study at precious junior and high school at Ciputat (1/A1) 
Marsela was an urban name of Marselamah. Marselamah itself was considered as villager's name. It was common to change someone's name to look cooler in the city, so that Marselamah changed her name into Marsela. This new name was considered to be more stylish because it sounded like European name.

The life of in big city was not easy. It was so complex that made people tended to live alone or being single. But, they believed that living in big city would give them better life. They wished about it, but they did not know when their wishes became true.

(2) ... In the fatigue life, there's no room to think about spouse in her mind. Moreover, when Jack flew to Europe ten years ago, Marsela's days was like the wind that blowing the stones. Without clatter and ripple.... Jack did not only make Marsela believed that Jakarta was a place for people from around the world, but also made her as the happiest woman in the world (2/A7).

(3) And with all that things, Jakarta seemed still being the option, and it still had its own charm for many people. ... (3/I13)

The main problem of metropolis lifestyle was about a pretense (falsehood). They did it to maintain their prestige.

(4) "No need to tell your real identity, La!" said Anis while teaching Marsela how to operate the social media. "Let's live destitute only in a real life, not in cyberspace. It's embarrassing if your old friends know that you're only a laborer!" (4/A20)

Even a pretense was done blindly and immeasurably.

(5) “Ah yeah, don't ride angkot tomorrow. Let's take a Busway and stop at Kadin Tower. Then, ride a taxi for a while. ... Get down a lil bit far from Jack Rabbit to keep your act save. Let say that you just get out from your Alphard and you can't park because your driver need to pick up your dress at Fashion House of famous designer at Kemang. And once again, don't forget to read the brochure of Singapore $i$ gave you yesterday. ... (5/A28)

Alphard (a series of expensive car brand) is a symbol of the establishment of high-class society, whereas the character in the story had low social status. This was proven by the mention of "fashion house", "famous designer", and the falsehood about Singapore which information was gained from the brochure.

\section{Social Environment}

The social environment is the context of life that is associated with the relational system among citizens. A number of social realities of metropolitan society are represented in the short story in the following quotation.

(6) I secretly admire the culture of Jakarta, not only its ondel-ondel and tanjidor, ...but, it's more than that, I admire how they build the sense of brother/sisterhood. Though they all come from different lands, they can appreciate the culture and character of each person from different region. Just like the housing complex that I'm living now, though on the other hand, we can not turn a blind eye to the problems of Jakarta. Traffic jam, fatigue, social disparity, individualistic, hedonic, criminal and so on. Full of colors. (6/F25)

Plural society became one of the indicators of how metropolitan society was represented in the short stories. Appreciating each others' culture and character became a basic things that needed to obey. It cannot be separated from our life context, the context as the nation's life (it is about living as a nation in a country). However, as a result of the various complexity of life (such as traffic jam, social inequality, life pressure, etc.), it made people busy to struggle for their better life.

(7) ... Ah, as for Marsela, the rising sun is no longer as a sign for a rising hope. On the contrary, she found that day by day million people's dreams are getting broken, crackling, wilting, and scattered (including hers). ... In her eyes, Jakarta is a giant cruelty mama. We have to call it Mama, and for those who refuse, there will be a gentle, subtle, yet painful torture for them. (7/A5)

Metropolitan city is considered as the city or the place for realizing people's dream and hope, but in reality it is just the opposite. The city only exhibits the character as cruelty giant that make its citizens tormented.

Plurality is not only about diffrent ethnic, but also about cross cultural understanding.

(8) At the age of three, Akiko attends International kindergarten school. Students from various countries gather here. Commonly, kids love to bring their dools like barbie dan panda inside their bag, but Akiko brings wayang kulit (shadow puppet). Her hands will grasp and move it up and down while singing and playing it. (8/C3).

The Akiko's character here was as the daughter of Japanese diplomat who had an interest in wayang kulit as traditional toys. There are other characters as well, for example Bona Sirait from Batak but interested in Javanese gamelan and song, Cut Mutia from Aceh who was talented and good at traditional Acehnese dance and Indian dance as well. 
The plurality that was represented in the short story also showed the tolerance among followers of certain religion. The mingling of various groups of people in relational ties who care for each other showed the lives of inclusive citizens.

(9) Mrs. Pho and her servant looked at each other. Her daughter is unseen behind the door. Mrs. Pho's heart is rowdy, her heart is at odds whether she would fire Babe or keep hire him considering his service so far. The sound of adhan broke their conversation. That's Mrs. Pho, alhough she is a fanatic Hokkian, but she is very tolerant of other religions. She asked the servant to do his maghrib prayer. (9/M21)

Another fact related to the social environment was the reality behind the luxurious skyscrapers, it is a shabby neighborhood.

(10) The man closed the window quitely. Yes, only a feasible simple house compared with the huts that grow like mushrooms along the banks of the river.... Long the ago, the Ciliwung river was clean, clear, and friendly, unlike today that becomes the enemy of Jakarta citizen when the water overflows during rainy season. (10/M22)

(11) She's startled and rubbed her eyes, suddenly she saw right in front of her eyes a watery turquoise river which was full of rubbish and fatigue of the city. (11/M24)

In the diversity of social conditions, metropolitan society still had a social feeling that lead to peer attention and empathy. It was represented by the overpowering character of Mrs. Pho who did not have the heart to fire Babe.

\section{The Relevance of Short Story for Literature Learning}

The social facts that were represented in JILFest 20082011 best short stories seemed to be a critical elaboration of the problems of Jakarta as metropolitan city. With the fictional strength of the short story the problems were expressed and presented in a more evocative manner. The complexity of social problems on the metropolitan city was packed in such a way that it offered a positive idea [3]. Sufficient understanding and meaning of this kind of quality required the proper learning process. Noticing the complexity of the subject and the style used in the short story, this short story material is suitable for high school students. It is because

high school students have a critical, logical, and systematic interpretation frame of mind. Furthermore, in order to maximize exploration and to ensure the sincere interpretation, understanding, and meaning of the social facts of the metropolitan community represented in the short story, we should design them to provide the learning space and opportunities for students for their freedom of interpretation (appreciation as their personal space), then exchanging ideas with other students or teachers (as a social space to sharpen the understanding of social issues that exist in the short story).

Furthermore, by applying the foundation of learning paradigm that emphasizes the learning activities of the students and obtains as much as possible impacts of learning (instructional and supplementary), it is necessary to design a group investigation with appropriate democratic context. As a notes, even in the process of group units and group work, a learning stage that provides individual space should be provided. This is as the actualization of personal space to appreciate. In this personal space (appreciation), students have the opportunity to devote their ability to capture the potential of short stories (ideas and beauty), as well as sharpening his potential for appreciation activities on other occasions.

In the group process, students discussed various social issues contained in the short stories. The first step, each student expressed his personal views, and then discussed critically the different views by utilizing the short stories as the data. The discussion does not mean to determine the right and wrong, but to sharpen and gain a better understanding. Such a way can extend students' insight and understanding of social issues, not only in the terms of what is presented in the short stories, but also in real-life social issues.

\section{CONCLUSION}

The best story of JILFest 2008-2011 reveals the lifestyle and social environment of the metropolitan community with a good fictional power so as to be able to realize the positive ideas and arouse social sensitivity. Democratic group investigation learning model can be used as the form of actualization for critical appreciation of literary learning. By this model, students can enjoy the idea and beauty of the short story, as well as gaining a good understanding of the contents of short stories and social problems in real life.

\section{REFERENCES}

[1] Ratna, Nyoman Kutha, "Paradigma Sosiologi Sastra", Pustaka Pelajar, 2009.

[2] Saryono, Djoko, "Dasar Apresiasi Sastra", Elmatera Publishing, 2009.

[3] Sejuta Warna di Langit Jakarta: Kumpulan Cerpen Terbaik JILFest 2008 \& 2011”, Komodo Books, 2011.

[4] Sunaryo, Hari dkk, "Model Adaptasi Kerifan Lokal dalam Pembelajaran Sastra Berkarakter", Jurnal Pendidikan Sains Sosial dan Kemanusiaan "Sosio Humanika", Vol. 10(1) Mei 2017.

[5] Sunaryo, hari, dkk. "Pengembangan Media Pembelajaran Sastra Berbasis Panggung", PUPT, 2016 